УДК 821.163.41-31.09 Петровић, Горан https://doi.org/10.18485/godisnjak.2020.15.15

Тања Д. Миленковић*

Универзитет у Београду

Филолошки факултет, докторанд
Оригинални научни рад

Примљен: 15. 09. 2020.

Прихваћен: 10. 11. 2020.

\title{
ОБЛИЦИ ФАНТАСТИКЕ У РОМАНУ ОПСАДА ЦРКВЕ СВЕТОГ СПАСА ГОРАНА ПЕТРОВИЋА
}

\begin{abstract}
У овом раду ће бити речи о начину формирања фантастике као жанра у роману Опсада иркве Светог Cnaca Горана Петровића. У средишту рада јесте описивање и набрајање типова фантастике у Oncadu и њихова компарација са типовима фантастике у другим делима овог писца. Уочавањем појединачних фантастичних мотива указује се на значај који фантастика има у делу као мотивација важнијих историјских догађаја (опсада Жиче, смрт царице Филипе), и издваја се улога фантастике као средства за другачије тумачење стварности и нови поглед на свет. Циљ анализе је стицање опште слике о облицима фантастике у роману Опсада иркве Светог Cnaca и приказивање значајних елемената Петровићеве поетике.
\end{abstract}

Кључне речи: фантастика, прича, пунозначна реч, пуноћа.

Одређење фантастике у прози Горана Петровића

Одређење жанра фантастике у делима Горана Петровића ће бити изведено уз помоћ поделе облика фантастике из Речника књижевних термина Тање Поповић, које ће као смернице у тумачењу бити коришћене у овом тексту: поетску, фолклорну, делиричну, социјално - утопијску, фантастику снова и сл., уз напомену да се ове подврсте често додирују и преплићу, те да их је тешко разлучити (211). Треба узети у обзир да „није могуће урадити систематизацију која ће бити у потпуности прецизна и која ће достићи степен универзалности" (Терић 2019: 35). Фантастика у

*tanjamilenkovic658@gmail.com 
Oncadu већим својим делом постоји као поступак којим су мотивисани и оправдани многи историјски догађаји (опсада цркве Светог Спаса, венчање Ане Дандоло и Стефана Немањића, аутокефалност српске цркве и крунисање Стефана Немањића за краља, смрт царице Филипе и василеуса Андроника Комнина и др.). Анализа је показала да су доминантни типови фантастике у овом роману: Средњовековна фантастика или пројекиија сакралног је можда најзначајнија, пошто се централни део фабуле, уздизање цркве на небо, дешава у оквиру тог облика фантастике. Ониричка ф. је важна као могућност ескапизма - јунаци беже из стварног света у снове (три мајстора), жене могу да буду трудне само у сновима (царица Филипа, Дивна), али се може умирати у сновима (Љубен, Филипа). У сновној фантастици је заступљено путовање кроз време (царица Филипа и Љубен соколар), што је облик научне фантастике; и гледање у будућност је у овом роману могуће путем Савиних видика и Шишмановог зденца. Фолклорна фантастика у којој је препозната крипто-бајка и епска ф. су значајне у карактеризацији антијунака кнеза Шишмана и Андрије Скадранина. Научна ф. или science fiction се налази у оквиру средњовековног слоја дела, где Бугари и Кумани граде механичку птицу која посредним утицајем служи за освајање света видинског кнеза Шишмана. Дела Горана Петровића одликује монтажа, комбинације различитих видова фантастике који се као слагалица беспрекорно уклапају један у други.

У књижевној терминологији под фантастичним се, у ширем смислу, подразумевају оне особине књижевних текстова које одређујемо као чудесно, натприродно и надстварно - од народне бајке до научне фантастике (Гагић 2017: 273). Основни облик фантастике који су проучаваовоци препознали у прози овог писца јесте поетска фантастика: „Ипак се доминантни стилски поступак у њима остварује у нивоу језика и стила и њихове поетски интониране синтаксе. [...] Оно што посебно означава Петровићеву синтаксу као поетску јесте преношење поетског значења текстова са мањих синтаксичких и садржинских јединица на веће, на прозни фрагмент и слику, на ширу прозну ситуацију и на значење целине прозне структуре" (Недић 2002: 324).

\section{Фигура чаробњака}

Присуство зла, тим путем и чаробњаштва, јавља се у мотивима као што су сушена тиква, раскршће, воденица, пет (тридесет) сребрњака, поломљени видици Савиних прозора, гавраново перо. Сушена тиква је атрибут демона у Oncadu, пошто се налази уз одређене антијунаке те сама 
по себи означава неко зло. У „Мељаницу” долазе два туђинца и траже да им се измеље садржај (речи добре о српској војсци) из сушене тикве, након чега долази до страдања војске. Андрија Скадранин носи сушену тикву са собом, као и Енрико Дандоло, који има једну у свом поседству. Зло је офантастичено: „Важан удео у изградњи фантастике романа има појава нечастивог у различитим обличјима и у временским различитим наративним токовима. Управо се у његовом присуству у роману преплићу границе фантастичног и реалног" (Алексић 2013: 160). Као чаробњаци су препознати Андрија Скадранин и дужд Енрико Дандоло, те ће бити разматране њихове особине злих волшебника.

Господар Андрија Скадранин је „трговац оловом, рујевином и перинама, а највише временом". Андрија Скадранин је један од најважнијих негативних јунака овог дела, али, за разлику од других, чија је мотивација стицање плашта од птичјих пера, односно, власти над читавим светом (кнез Шишман, Енрико Дандоло), Андрија жели да њему припадне читава будућност. Андријин лик је чаробњачки, не само делање и намере: „Ходао је тешко, повлачећи ону ногу обувену у чизму са заденутим пером гаврана, не растајући се од једног дугачког штапа којим се помагао, па ипак, зачудо, ни у расквашеној земљи не остављајући трагове стопала" (Петровић 2009: 69), што одаје утисак да он у ствари и не постоји. У роману су персонификовани многи грехови и особине, раскрсница сујете (Свети Сава), извор таштине (краљ Милутин), поток самоуверености (Ариф) господин Андрија би могао да се тумачи као персонификована похлепа, због везе са новцем и трговином.

Са господаром Андријом су повезани чаробњаштво и магија, као и сплетке и подлости. Осим трговине временом и причом, Андрија Скадранин поклања пет сребрњака Дохијару Данилу, они се множе до броја тридесет и одржавају тај број без обзира на то колико новчића он одузео. Пошто трговац тргује временом, позната му је вештине крађе времена као крађе предмета; украо је четрдесет будућих година од Жиче. У Западним земљама у будућим годинама је нудио да направи „механичку направу која се храни свежим временом" (Петровић 2009: 358), што се може разумети да је изумео часовник. Господар Андрија, будући да нема порекло, прилагођава се времену и околностима у којима је; у двадесетовековном слоју зове се Андреас фон Нахт, и важан је део биографије протагонисте Богдана, чију будућу жену Дивну Тановић „лови” зли волшебник. У поглављу „Фолклорна фантастика” та улога Андрије Скадранина је препозната као улога змаја у архетипској бајковној причи о принцу који убија змаја и спасава принцезу. 
Капија светова: поломљено огледало

Механик Ариф, који је „знао напамет све мере света”, тврди да се не могу наћи две подударне мере „чак и када се у новом, само за ту прилику раздевиченом огледалу одражава” (Петровић 2009: 137). „Раздевичено” или поломљено огледало је магични портал кроз које пролазе јунаци из света живих у свет мртвих и обратно. Господар Андрија уходи Богдана и Дивну јављајући се путем поломљеног огледала: „указивао се све чешће наизменично на телевизији и у препуклом огледалу, све се теже могло јасно разлучити која га од ове две направе више умножава" (Петровић 2009: 220). Могуће је да се ради о неколико стварности и повезаним световима за које зна трговац временом, те се беспрекорно креће међу њима. Чак и Богдан познаје могућност ходања међу световима: „,...] да би се дошло до пера жар-пице, морало се ићи и погибљеном уском стазом између сна и јаве” (Петровић 2009: 337), док механик Ариф тврди да не постоје две једнаке стварности. Свет Опсаде иркве Светог Cnaca је подељен између неколико светова и вере јунака у њих: „Скуп свих могућности дели се на „много различитих комбинација могућности [...] Постоји много могућих универзума, а сваки од њих је својеврсна колекција компосибилности" (Долежел 2008: 31).

\section{Енрико Дандоло}

Други чаробњак је дужд од Млетака, Енрико Дандоло, чија су деловања и потези мотивисани фантастиком. Постоји предање у којем дужд поседује сушену тикву у којој је „непотрошиви, многожути глиб из сваког од девет кругова доњег света” (Петровић 2009 : 153) коју му је донео сам Непоменик. Фантастика се протеже у два правца, поменута сушена тиква има везе са Ђаволом и у њу је смештена некакава ђавоља твар, земља из пакла. Земља из сушене тикве је повезана са недокученим злим намерама које Дандоло има са узорцима земље из читавог света које му доносе поданици. Може се претпоставити да је земља као и плашт само једно од средстава за завладавање светом.

Плашт од десет хиљада пера који ће донети власт над читавим светом се састоји од пера различитих птица, за којим трагају владари у средњовековном слоју романа. Енрико Дандоло тражи плашт од принца Алексија Анђела, покреће крсташе из Јерусалима да иду у поход на Византију наводно због увреде коју су папи нанели Византијци, али у ствари само из личне користи, да узме плашт из сефа василеуса Алексија V Дуке 
Мурзуфла. У неколико наврата Енрико Дандоло описује плашт чудесних моћи: „Плашт о којем ти говорим није од племените тканине, није везен бисерима, нити постављен крзном од самура. Без златних је копчи, није помодног кроја. Просте је израде, наиме, сачињен је од птичјих пера" (Петровић 2009 : 158). Плашт може и да се схвати као плацебо, односно, јунаци верују да ће им он дати моћ, али у ствари их та вера води у акцију.

\section{Значај речи и приче}

Речи могу бити празне и пунозначне, а само пунозначне речи доводе до пуноће и истине. Само перо од живе птице пише одређену пунозначну реч, где се прави веза између пера и речи, птице и речи, птице, анђела и истине. Истини се тежи у овом делу и кроз Савине видике и Богданов висак. Прича „Речи” из збирке Ближњ и носи мисао која је фундаментална за важност речи Горана Петровића: „Ко једанпут осети пуноћу речи - довека испашта јер препознаје празно казивање" (Петровић, Унутрашње двориште 86) и, најзад, „речи су или пуне или празне, само неки знају њихово право значење" (Петровић, Унутрашье двориште 230). Због тога су речи на привилегованом месту, уз њих и прича. Лајтмотив романа је да је прича о човеку важна као сам човек, без приче нема човека. У наставку рада биће наведени примери који доказују ту тврдњу.

\section{Буквализација тропа}

Речи се третирају као предмети у свету Oncade: „Госпе су своју отменост доказивале носећи детаљно приповедане драге каменове. А дешавало се да вечера буде послужена у препричаном византијском посуђу", као што у причи „Речи” саме речи творе предмете. Препричана лепота може да се сачува у кутији: „шкрињицу од ружиног дрвета начинио, да у њој од бура чува младићке црте” (Петровић, 2009: 203). Поморац нуди јуродивом Блашку да му плати у злату или у причи за кутију коју му је направио, Блашко бира причу: „Поред земаљског растиња, рече ми онда поморац, дрвеће ниче и у горњем Врту” (Петровић 2009: 203). Блашко је дрводеља и животна мисија му је да дозна како да дође до Еденске баште, зато лута по манастирима као јуридиви.

Рат који воде Бугари и Кумани са српском војском је рат речима $u$ причом. Бугари и Кумани „имају трагаче за зечијим брабоњцима [...] уједно скупљају и све гласе што поход около себе оставља. Видински кнез има и једну летећу утвару, звану цекавац. Она уклања гласе из висова" (Пе- 
тровић 2009: 113), док српска војска има теклиће и примућура који лове у мрежама приче и гласове. Дакле, ако прича о доласку војске на српску територију не дође до краља, Бугари и Кумани могу да учине ванредну штету и да уђу у срце државе. Када коначно Бугари и Кумани на челу са кнезом Шишманом дођу до манастира Жиче, који је већ изнад земље, сусрећу се са речима оца Григорија: „Капа од живог риса скочи са главе видинског господара, пегава звер искези губицу, очас шчепа простодушне игуманове гласе, стаде их дивље трзати зубима, раскида им смисао, тло порска сврха" (Петровић 2009: 134). Доследно је постигнута метафора гласа као тела, смисла као ткива, а сврхе као крви. Као што је речено, рат се води на нивоу речи и приче, а овај покушај дипломатије од стране игумана је дословно убијен.

\section{Одсуство речи}

Недостатак речи, односно ћутња, има симболику важну као и речи. Казна која је јако важна према метафори приче и приповедања, јесте гора од смрти, ваљање у ништа. Наиме, то је казна за оне који разочарају и разгневе видинског кнеза: „Свако је био дужан, без обзира на висину положаја, да преда све што зна о два несрећника. Све. До последњег гласка. [...] О њима се више није смела започињати или настављати било каква, ма и најмања прича" (Петровић 209 : 45). Кажњеницима речи и прича о њима испада када за казну буду окренути наглавачке, где је буквализовано „испадање речи”. Такође се посеже за „чупањем речи гвозденим машицама”, што је метафора „чупања речи из уста”. Када отац од Дивне Тановић прода причу о њој Андреасу фон Нахту, Дивна физички нестаје у унутрашњем дворишту своје куће јер „вавеки умире само онај о коме нема никаквог помена" (Петровић $2009: 285)$. Бугари и Кумани имају трагаче за зечијим брабоњцима који скупљају причу о проласку војске, тако могу да дођу до Жиче неометано: „Поход се ближио немо, као језовита ћутња” (Петровић 2009: 116). План кнеза Шишмана за освајање Жиче јесте „свући одозго ту њихову причу, развући што је вредно, остало спалити до потпуне ћутње!” (Петровић 2009: 303). Ћутање о једном народу представља нестајање тог народа, јер: „Нису многи народи нетрагом нестали што су имали одвише непријатеља, већ стога што није било ничега да се сатвори о њима." (Петровић 2009: 288). Неми говор избеглица у двадесетовековном слоју сведочи о патњама које доносе вечне сеобе Срба. 


\section{Ониричка фантастика}

У опусу Горана Петровића сновна фантастика се налази на привилегованом месту. Важну улогу сан има у роману Атлас описан небом, где јунаци посећују једни друге у сновима, у сну је „Запис” за којим трагају Љиљии Потковичари; такође, сан може да буде украден. У причама „Трска” и „Месец над тепсијом”, које припадају збирци Острво и околне приче, остварена је метафора сна као ваздуха и јаве као воде, јер јунак удише сан трском, да га јава не би угушила. У Ситничарници 'Код срећне руке' Адам Лозанић сања: „А онда је сањао - страшне ли море! - да се пробудио и да ништа више не може да сања" (Петровић, Ситничарница 109). Изводи се закључак да је сан у делима Горана Петровића, чак и у онима где није доминантан, везивно ткиво других облика фантастике. Постоје одређени услови које испуњава фантастика снова: наиме, „када је одређени сан испуњен фантастичним садржајем који не излази из тог оквира већ егзистира само у том простору, не можемо говорити о фантастици. Дакле, сновна грађа мора бити дио стварног свијета и утицати на његово даље конституисање" (Терић $2019: 35)$. У Опсади су сви догађаји у сну тесно повезани са стварним светом романа (Филипа и Љубен и путовање кроз време, три поочима, крађа снова и елемената из снова и др.), тако да се, говорећи о њима, без сумње ради о ониричкој фантастици у правом смислу речи.

\section{Дијалог са Павићем}

Треба посматрати ониричку фантастику у Onсади иркве Cветог Cna$c a$ као јединствену, али и у поређењу са ониричком фантастиком Милорада Павића, јер се на неким местима може приметити дијалог са Павићевим Хазарским речником. Дијалог са Павићевим ониризмом се огледа у две значајне тачке, у лову у сну и са пророчким сном: „Најприсутнији облик ониричке фантастике заснива се на пророчком/профетском сну, који говори о догађајима који ће се у будућности одиграти” (Терић 2019 : 36).

\section{Пророчки сан}

Пророчки сан у Хазарском речнику се може упоредити са пророчким сном у Oncadu, јер је, наиме, каган уснио судбоносан сан, како му је анђео Господњи рекао: „Творцу су драге твоје намере, али твоја дела нису” (Павић 2012 : 125). Сан је окидач за каганову одлуку да он и хазарски народ пређу у вероисповест пророка који најверодостојније протумачи значење 
кагановог сновиђења: „Каган је затражио од свог свештеника, ловца на снове, да му протумачи сан, али пошто је био незадовољан тим тумачењем, разљутио се и позвао странце. Тако је изазвана хазарска полемика" (Делић 1991: 99). Компаративно са кагановим сном, у Oncadu један од главних антихероја, видински кнез Шишман, сања чудан сан и зове тумаче да га протумаче: „Сних да дуго, круг за кругом, тонем у некакво вртло... [...] А онда доспех на дно... [...] Да бих сањао само потпуни мрак!” (Петровић 2009: 308). Након тог сна, одлучује да донесе мрак манастиру Жича.

\section{Лов у сну}

Други важан вид дијалога са Павићем је Лов у сну: „Мит о Еросу се у Хазарском речнику огледа на више места, а најважнији је у „Зеленој књизи” где Адам Рухани (анђеоски предак човека о којем говоре имами), „попут нас у сну ни он није могао да убије или оплоди” (Павић 2012 : 137). Петровићеви јунаци организују лов у сну где могу да убију: „Крајем XIV века сваки лов у сну деспота Стефана Лазаревића беше веома посећен од многих славних људи тог ранијег доба. [...] Тако је, тамо (мада је на јави умро 1185. године), једном приликом смртно завшио од крилате море и василеус византијски, охоли Андроник Комнин” (Петровић 2009 : 230). Ограничење Ероса у сну бога и анђела такође превазилазе јунаци Onca$\partial u$, жене могу да занесу и да рађају децу. Византијска царица Филипа и Дивна Тановић су пример претходне тврдње: „Посебан прогон чекао је жене што занесу у ноћи пуног месеца. Веровало се да у њима зри нарочит плод, новорођенче које ће доцније казивати приче кадре да се супротставе деспотској владавини. Такве би се жене познавале по томе јер су бремените само у сну, али зато што и дуже но обично носе, барем двадесет седам месеци" (Петровић 2009: 230).

\section{Путовање кроз време}

Путовање кроз време спаја научну и ониричку фантастику у овом делу: „путовање кроз време је такође право, а не алегорија трагања за изгубљеним временом [...]”. (Терић 2019: 38) Царица Филипа путује двеста година унапред у свом сну, у којем среће свог изабраника Љубена, који путује кроз сан и умире у сну свог сина Богдана. Љубен путује да би срео Филипу: „са имовином од једног јединог крагуја пође за сањаном, а изгубљеном пуноћом" (Петровић 2009: 32). Потрага у Oncadu је у ствари 
за пуноћом која је у облику љубави, птице, поведања, пунозначне речи, а за антијунаке, у облику плашта од десет хиљада пера.

\section{Никејски прозори Светог Саве}

Важно за многе нити ове приповести је уплив ониричке фантастике у причу о Сави Немањићу и Стефану Немањи. Сави је у сан дошао отац и наредио му је да иска од васељенског патријарха четири никејска прозора за цркву Светог Спаса. Прозори су важни за фабулу овог дела јер се прича о њима простире до двадесетовековног слоја романа. Сваки прозор је јединствен и има своју сврху: „Видици са спрата припрате цркве Св. Спаса не иду само на четири стране света, већ се пружају и у сва четири главна времена" (Петровић 2009: 31). Кроз прозоре, дакле, може се видети прошлост, садашњост у близини Жиче и садашњост на другим местима, као и будућност: „Први је прозор онога садањег, други и трећи прозор служе за шта је било и шта ће бити. Кроз четврти прозор „Сава је могао видети све како и јесте, али све како је јесте не одмах испод, него испред, на неколико даљина. Прозори не показују само време, већ и истину: „Без њих, Господе, нећемо знати какви смо збиља били! - Ни какви збиља можемо да будемо! - Без њих, Господе, нећемо разазнавати шта нам други уистину сплићу! А шта себи самима уистину спремамо!” (Петровић 2009: 369). Никејски прозори су на буквалном плану портали за гледање у друге светове, јунаци гледају времена као што се гледају простори. Гледање у будућност постоји још на једном месту, кад слуга кнеза Шишмана гледа у зденац будућности.

Долази до судара светова, када Андрија Скадранин отвори прозор будућег времена, који није био на реду, што је кључни захтев Стефана Немањића: „Уздам се да видике нећете смрсити. У супротном, нека нам је Господ на помоћи, путеви су нам у чвор везани, раздрешити их неће моћи стото колено од овога места" (Петровић 2009: 32). Двадесет осмог дана опсаде Жиче на Водену суботу игуман Григорије је открио да је „наместо садањег на даљину, био је раскриљен прозор будућег времена [...]. Отворено пре рока, будуће време није довољно дозрело. Развило се тек неколико година унапред манастира" (Петровић 2009: 334), као што је кнез Шишман хтео: „да се свако српско време, и прошло, и садање, и будуће, распе у недоглед!" (Петровић 2009: 303). Господар Андрија Скадранин је похарао манастир за четрдесет идућих година у којима је Жича остала у манастиру, док је молитвом није спустио архиепископ Дианило Други. Архиепископ Јевстатије Други је 1293. дошао да сахрани пострадале и 
извиди шта је остало од Спасовог дома. Видици жичких прозора су били поразбијани, те су их сакупљали „у изломљено приповедање”.

\section{Богдан и Савини видици}

\section{Офантастичени вид}

Поглед има фантастичне одлике, што се примећује на много места, од имена Богдановог цимера у затворској ћелији (који се зове Видосав), затим његова фантастична моћ гледања у плафон да би га подупро погледом да му не падне на главу, напослетку, Видосав црта угљеном по зидовима прозоре који се претварају у хиљаде фантастичних видика које показује Богдану. У затвору је зато што је видео нешто што није требало, као и Богдан: „Ваљало је сакрити прави смисао. Или, макар, преиначити све што указује на стварни поредак ствари" (Петровић 2009: 187). Видосав открива Богдану да не постоје стварни прозори, где му указује на предање о Савиним видицима, објашњава да су „доследно зазидани сви прозори до садањег доба" (Петровић 2009: 186). Богдан од Видосава добија висак који му служи да упореди видике са прозорима, односно, да тражи скривену истину: „Препознаћеш онај истински прислониш ли уз њега ову справу. Само уз такав отвор, висак ће стајати подударно. Лажни прозори увек су постављени бар мало укриво" (Петровић 2009: 191). Висак у Богдана је нешто као чаробни елемент јунака бајке, док Видосав има улогу чаробног помоћника, о чему ће бити речи у поглављу „Фолклорна фантастика”. Богдан је прислонио висак уз један прозор кад је изашао на слободу и закључио: „Рат је већ увелико трајао, а прозори нису показивали ништа од онога што се заправо дешавало" (Петровић 2009: 192). У потрази за истином Богдан разговара са људима који су довољно храбри да сумњају у сопствени вид и да преиспитују стварност: „стално другачије постављена окна Богданове збиље, само су иницијације новог споразумевања. Дабогме, и са прошлошћу" (Ређеп 1998: 791). Богдан схвата да је зашао у прозорски лавиринт у којем је Аријаднин конац пунозначна реч: „речи су један од оних ретких лавирината које зло још увек није разрешило, у којима још увек може, барем привремено да залута" (Петровић 2009: 333).

\section{Богдан и прича}

Богдан је почео да се брине о поведању, јер му његови сународници нису дозволили да се брине о видицима и стварности. Сакупља перје различитих птица, јер свака реч има своје перо за писање пунозначне речи: 
„Сваки час пуцала понека реч, одвише разапета између пуног и правог значења” (Петровић 2009: 335). Јуродиви Блашко је предвидео: „у повест човек може и пред највећом несрећом да се заклони. [...] настави ли да се надима својим наводним знањем, заиста је питање да ли ће људски род, убудуће, моћи да стане у приче" (Петровић 2009: 203). Богданово време је управо оно у којем више нема приче у којој човек може да се сакрије. У поглављу „Одметнути приповедачи, тиранија властелина историје” објашњава се моћ деце рођене у сновима: „новорођенче које ће доцније казивати приче кадре да се супротставе деспотској владавини [...] Са надом у нови, бољи род” (Петровић 2009: 230). Назив последњег поглавља у књизи, „Конац или почело”, сугерише да није крај приче о причи, већ почетак нове приче. Крсти се дете од Богдана и Дивне које је изузетно као и он, пошто је рођено у сну, стога је суђено да настави пут старања о поведању и пуноћи.

\section{Фолклорна фантастика}

У свету Oncade је препознато неколико видова фолклорне фантастике, прецизније, елементи бајке, разни мотиви из епске поезије и митолошка бића из усмених предања и народних веровања, и на концу, хронотоп демонског места је остварен према угледу на фолклорни образац: „Фолклорна фантастика почива на усменом стваралаштву, разним предањима, вјеровањима и обредима, карактеристичним за период средњовековне књижевности. Ова врста грађе коришћена је у предромантичарској епохи, тако што су се аутори служили елементима фолклорног материјала, умјетнички их прерађивали и интегрисали у текстове” (Терић 2019: 37). Судећи према важности фолклорне ф. у овом делу, произилази да „фолклорна фантастика остаће главни извор грађе чак и за модерну српску фантастику" (Гагић 2017: 274).

\section{Крипто-бајка у Опсади иркве Светог Cnaca}

Onсада иркве Светог Спаса садржи елементе бајке. Као прилог тој тврдњи се може посматрати један од главних јунака, Богдан, који се понаша као архетипски протагониста бајковног наратива. Богдан је племенитог порекла, син од царице; рођен је као дете изузетних способости због чињенице да је рођен у сну. Има херојску мисију царевића, не да убије змаја (као змај, односно врховно зло, може се посматрати Андрија Скадранин, од којег Богдан штити Дивну Тановић), већ да буде један од 
ретких људи који трага за истином помоћу виска, који је чаробно средство дато од чаробног помоћника Видосава: „Иако има централну позицију, главни јунак бајке максимално зависи од демонских и митских 'саучесника' у радњи" (Самарџија 2008: 286). Богданова мисија је и да трага за пуноћом и пунозначним речима. У потрази му помажу птице, које се, сходно тврдњи, понашају као чаробни помоћници, остављајући му своја пера на местима где може да их узме. Богдан спасава изузетну лепотицу Дивну, која се третира као принцеза са свим описима тоалете и магичних поклона које ниједна друга девојка нема (сунчеви зраци са Лида, срмена француска месечина са Ривијере, свежина са Луганског језера, октобарска позлата из Прага итд.). Јунак добра срца оживљава заробљену госпу из унутрашњег дворишта и спасава је од злог чаробњака Андреаса фон Нахта и бежи са њом код, опет, чаробног помоћника, господина Исидора: „И главни јунаци бајке имају пред собом јасан циљ, као и епски јунаци. Циљеви су понекад веома слични, јер прате пут ослобођења отетих девојака или уклетих градова и борбе против рушилачких, хтонских сила" (Самарџија 2008: 286).

\section{Епска фанастика у Oncadu}

Епска фантастика у Oncadu је богата и ослоњена на обрасце и формуле народних песама и народних предања: „Јуначки коњи и оружје битни су сегменти описа и читаве епске биографије. [...] Најбољим витезовима и ратницима пипадају изузетни атрибути, са којима се јунак идентификује. Из перспективе епског кодтекса губљење тих атрибута значи да је њихов господар погинуо или је срамно поражен" (Самарџија 2008: 40). У Oncadи изузетни јунаци имају јуначке атрибуте какве су некада имали јунаци епских народних песама: птица (крагуј извијаш соколара Љубена), коњ (белац царице Филипе) и пси (ветрови бугарског краља Калојана).

Ако су јунак и његов јуначки атрибути нераздвојни, и раздвајање значи смрт, онда зато када Љубену крагуј одлети са груди, Љубен одмах умире: „Такву подлогу изразитије испољава дијалог између сокола/орла и рањеног јунака, као потврда безизлазне ситуације или најава смрти, а сама птица постаје спасилац или водич у онај свет" (Самарџија 2008: 77). Улогу Богдановог анђела чувара има „душа соколара Љубена која се трансформише у крагуја извијаша пратећи сина до краја романа" (Арбутина 1998: 69), те је та веза још продубљенија у теолошком смислу.

Коњ царице Филипе је чудесан зато што је води у свет сна и прелази са њом двеста година до сна соколара Љубена. Коњ је у тој сцени уједно 
јуначки атрибут и магични помоћник, те се његова улога ослања на матрицу бајке и епске песме. Слика царице која путује кроз мрак у свету снова, као и њен први сусрет са Љубеном, где је он брани од ноћних птица, подсећа на Психино спуштање у Пакао, у хтонски свет (Ерос и Психа). Коњ је остао поред царице Филипе кад је она умрла на порођају, стога се присуство белог коња може посматрати као спровођење у царство мртвих: „Коњ, иначе честа жртвена животиња, попут јелена одводи душу умрлих на онај свет, због чега се посебно коњ погинулог јунака оставља крај његовог тела" (Самарџија 2008 : 61).

Ветрови бугарског цара Калојана су у ствари персонификовани јуначки атрибути, пси: „где год кренуо, за собом је, на ланцу, вукао још седам најмилијих дувала" (Петровић 2009: 272). Укључивање пса у атрибуте епског јунака везано је махом за сцене лова, а по изузетку су љути „лавови” саставни члан приказивања попришта, са којег се јунаци неће вратити (Самарџија 2008: 74). Бугарски цар Калојан је јунак који је учествовао у поразу дужда Енрика Дандола, стога придавање ветрова, у пренесеном смислу, паса баш њему, није случајно.

Дијаболични изглед бугарских и куманских ратника се може објаснити културолошком разликом између странаца и богобојажљивих српских монаха за које су неверници визуелно - демони. Многострашни кнез Шишман има најупечатљивије атрибуте у оквиру епског портрета. Капа од коже риса није само украс који треба да застраши непријатеља, већ је то капа од живог риса која једе смисао речи. Оковратник му је од живих куна златица, а појас је жива змија што једе свој реп (Уроборос). Најопаснији елеменат кнежевог многострашног изгледа је цикавац који лови речи о војсци из ваздуха, да не дођу до српских ушију. Атрибути кнеза нису само живописни, офантастичени, што га чини посебно динамичном фигуром која је осмишљена, могуће, као омаж јунацима епских народних песама. Кумански вођ Алтан је осликан као демонски помоћник који је „човечина обријаног темена и распуштеног држања, ратник велике лепоте, док се не насмеје и покаже све очњак до очњака" (Петровић 2009: 38). Алтанова улога у роману претежно се своди на улогу приглупог лепотана који је у већини својих појављивања у еротском сусрету са наложницама, што га повезује са архетипом змајевитог љубавника епске народне традиције (Царица Милица и змај од Jастрепиа).

Хтонско место, по угледу на народна предања, у овом делу је воденица и доба дана је, наравно, ноћ: „Воденица, поготово ако је забачена, урушена, јесте маркирани локус, место боравка митолошких ликова” (Толстој, Раденковић, „Воденица”, 2001: 90). Оно што је ново и фантастично 
у овој сцени јесте то што демони не желе из глади или обести да нашкоде млинару, већ да млин из сушене тикве: „у саструг претвори речи добре” јер воденица „круни зле гласе, ноћу обрнуто меље” (Петровић 2009: 105). Нечисте силе које су дошле у ноћ припадају кнезу Шишману који их је послало да самељу гласове српске војске која се изгубила у мраку, да не би могла да дође до бугарске и куманске војске, као и да би несметано могли доћи до пера анђеоског из браде игумана Григорија.

\section{Средњовековна фантастика или пројекција сакралног}

Према проучавањима Саве Дамјанова, пројекција сакралног је један од три типа фантастике српског предромантизма: „Пројекција сакралног, као посебан тип фантастике, везује се за подручје религијског, хришћанског кода, у коме владају закони оностраног, небеског свијета који контролишу овоземаљска збивања. Ријеч је о разним чудима свијетаца, визијама, преображајима и другим оностраним знамењима. Главни покретач ових збивања јесте божанска сила која управља свијетом. Стога се фантастичко не конституише постепено, већ се одједанпут претвара у реалитет. То значи да је пројекција сакралног заснована на немиметичким принципима стварања" (Терић 2019: 37).

У средњовековној духовности молитвом може било шта да се постигне, ако се верује, и ако је на корист свих људи оно за шта се моли. Уздизање цркве на небо само је једно од божјих милости и чудеса, не фантастика, за људе тог доба: појам фантастике зависио је у средњовековној српској књижевности, као и у целом хришћанском свету, пре свега од библијске митологије и црквених учења. Без обзира на то из чега је проистицала, на шта се наслањала и шта је све у себи прерађивала, хришћанска догма је своју есхатолошку философију овог и оног света градила на вери у чуда, која једина могу одржавати везу и склад између видљивог и невидљивог (Палавестра 1989: 16). Уз помоћ молитве монаси подижу у небо Жичу, архиепископ Данило Други је спушта на земљу након четрдесет година.

Од најезде Бугара и Кумана који су намерили да изврше опсаду цркве Светог Спаса, монаси нису знали како да се изборе, пошто је војска краља Милутина и краља Драгутина имала тешкоће при путу ка Жичи. Отац Спиридон је изнео мисао да је „молитви свуда место” и према томе они треба да поступе као монаси Ватопеда пред гусарском навалом, да молитвом манастир подигну на небо. Свети Симеон и Свети Сава су молитвом призвали војску арханђела, што је топос спаса од непријатеља у житијима (житије Данила Другог). Улогу посредне божије помоћи је 
у преходним нападима на цркву имало перо архангела. Приказани тип помоћи се у науци о књижевности означава као Deus ex Machina, силазак Бога са небеса и помагање јунацима у безизлазној ситуацији.

\section{Научна фантастика или science fiction}

Прављење механичке птице је препознато као научна фантастика јер се у научној ф. „међусобно преплићу измишљено, надстварно и чудно, са научним проналасцима и њиховим реалним образложењем" (Поповић 2010 : 211). Грађење механичке птице може да буде кобно по човечанство, јер ако се кнез Шишман домогне анђеоског пера, може да загосподари светом: „Још једна битна одлика ових романа јесте дословно схватање првог значењског нивоа текста, што значи да је његово алегоријско и симболичко декодирање искључено. Да појаснимо „робот у научној фантастици је робот, а не симбол механизације човековог унутрашњег бића, путовање кроз време је такође право, а не алегорија трагања за изгубљеним временом" и тако даље (Терић 2019 : 38). Од првог напада на манастир се најављује механичка птица коју гради Сарацен Ариф. Четврти и последњи напад на цркву Светог Спаса у књизи „Начала” се десио када је механичка птица коначно полетела и напала манастир који је почео да тоне са висина. Опсадници нису успели да спусте Жичу јер је игуман још једном ослободио перо анђела из браде-реликвијара и обезбедио спас цркве Светог Спаса.

\section{Извори}

Петровић 2009: Г. Петровић, Опсада иркве Светог Cnaca, Београд: Plato Books, 2009.

Петровић 2012: Г. Петровић, Атлас описан небом, Београд: Моно и Мањана, 2012.

Петровић 2018: Г. Петровић, Ситничарница 'Код срећне руке', Београд: Laguna, 2018.

Петровић 2019: Г.Петровић, Унутраиъе двориште, Београд: Лагуна, 2019. 


\section{ЛИТЕРАТУРА}

Алексић 2013: Ј. Алексић, Опседнута прича: поетика романа Горана Петровића, Београд: Службени гласник, 2013.

Арбутина 1998: П. В. Арбутина, „Византија између неба и земље Опсада цркве Светог Спаса", Книжевна реч год. 27, бр. 501 (1998): 69.

Гагић 2017: С. П. Гагић, „Наше ноћне море: Фолклорна фантастика у филмовима „Лептрица” и „Свето место” Ђорђа Кадијевића”, Годишњак Катедре за српску књижевност са јужнословенским књижевностима, Ур. Бошко Сувајџић, Београд: Чигоја штампа, бр. 12, 2017, 273-293.

Делић 1991: Ј. Делић, „Кључни принцип броја три у Павићевом Хазарском речнику”, Хазарска призма, тумачење прозе Милорада Павића, Београд: Просвета, 1991.

Долежел 2008: Љ. Долежел, Хетерокосмика: фикиија и могући светови, Београд: Службени гласник, 2008.

Недић 2002: М. Недић, Основа и прича: огледи о савременој српској прози, Београд: „Филип Вишњић”, 2002.

Нови завјет Господа нашега Исуса Христа, Прев. Вук Караџић, Београд: Библијско друштво, 1993.

Павић 2012: Павић, Милорад, Хазарски речник, Београд: Завод за уџбенике, 2012.

Палавестра 1989: П. Палавестра, „Одлике српске фантастике”, у: Српска фантастика: Натприродно и нестварно у српској књиюевности, Књ. бр. 4, Ур. академик Предраг Палавестра, Београд: САНУ, Одељење језика и књижевности, Научни скупови, Књ. 9, 1989, 9-31.

Поповић 2010: Т. Поповић, „Фантастично.”, Речник књижевних термина, Београд : Logos Art, 2010.

Ређеп 1998: Д. Ређеп, „Никејски прозори Горана Петровића”, Књижевност, год. 52 бр. 3/4 (1998): 790-792.

Самарџија 2008: С. Самарџија, Биографије епских јунака, Београд: Библиотека „Књижевност и језик”, књ. 27, Друштво за српски језик и књижевност Србије, 2008.

Терић 2019: М. Терић, Унутрашња страна времена-Фантастика у роману „Унутрашња страна ветра” Милорада Павића, Цетиње : Факултет за црногорски језик и књижевност - Цетиње, Библиотека Посебна издања Књ. 19, 2019. 
Толстој, Раденковић 2001: С. М. Толостој, Љ. Раденковић, „Воденица", Словенска митологија: енциклопедијски речник, Београд: Zepter book world, 2001.

Tanja D. Milenković

\section{THE TYPES OF THE FANTASTIC IN „THE SIEGE OF THE CHURCH OF THE ST SALVATION" OF GORAN PETROVIĆ}

\section{Summary}

In this paper will be evaluated the manner of the forming the fantastic like a genre in the novel "The siege of the church of the St Salvation". In the center of the analyses in the paper is the description and counting the types of fantastics in "The siege" and their comparison with the types of the fantastic in the prose of this writer. With acknowledging specific fantastic motives it is indicated the significance which fantastics has like an instrument for the different interpretation and the new view on the world. The purpose of the analyses is the earning the general view of the types of the fantastic in the novel "The siege of the church of the St Salvation" and representation the most significant elements of the Petrović's poetics.

Key words: fantastic, story, meaningful word, fullness. 